\title{
TAGIT KNOWLEDGE: SOME SUGGESTIONS FOR OPERATIONALIZATION
}

\author{
VÉronique Ambrosini \\ Cliff Bowman \\ Cranfield University, Bedford
}

\begin{abstract}
With the emergence of the resource-based view of the firm and of the concept of core competencies, intangible resources, and tacit knowledge in particular have been argued to occupy a central place in the development of sustainable competitive advantage. This is because tacit knowledge is argued to be difficult to imitate, to substitute, to transfer and it is rare. However, there is little empirical research to support this theoretical proposition. Tacit knowledge has so far resisted operationalization. This paper sets out to define the term tacit knowledge and proposes to redefine it, within the context of the resource-based view of the firm, as tacit skills. A methodology (based on causal mapping, self-Q and storytelling) for empirically researching the subject is outlined.
\end{abstract}

\section{INTRODUCTION}

Nonaka (1991), Grant (1993) and Spender (1993) have argued that tacit knowledge occupies a central role in the development of sustainable competitive advantage. Tangible resources can be purchased or replicated, and hence, Grant (1993) and Sobal and Lei (1994) assert that knowledge, and notably tacit knowledge, is one of the most critical resources of the firm. They justify this position by arguing that, because of the ability of competitors to quickly acquire some types of resource, 'sustainability of competitive advantage ... requires resources which are idiosyncratic ... and not so easily transferable or replicable. The criteria point to knowledge (tacit knowledge in particular) as the most strategically important resource of the firm' (Grant, 1993, p. 2). All this strongly suggests that tacit knowledge is an important phenomenon to study. Nevertheless, tacit knowledge has up to now resisted operationalization. The literature as a whole has remained conceptual. Indeed, to quote Rao (1994), 'despite widespread agreement among organisational researchers that intangible resources underlie performance differences among organisations, little empirical evidence exists in the literature' (p. 29) and there is a 'need to know much more empirically about the nature of tacit

Address for reprints: Véronique Ambrosini, Cranfield School of Management, Cranfield University, Bedford MK43 0AL, UK. 
knowledge for it to become a theoretically coherent and convincing . . . construct' (Jensen, 1993, p. 9).

In what follows, we set out the premises of a methodology that should allow us to empirically study tacit knowledge and explore whether it can indeed be a source of competitive advantage. However, before doing so, we start by defining tacit knowledge and argue for the use of the expression 'tacit skills' rather than 'tacit knowledge'. We also justify why 'tacit knowledge' is a 'resource' as defined by the proponents of the resource-based view of the firm (Barney, 1991; Peteraf, 1993). In this paper we concentrate on tacit knowledge as a valuable resource. We are however well aware that there can be a 'dysfunctional flip side' (Leonard-Barton, 1992, p. 111) to resources. Resources may become 'competency traps' (Levitt and March, 1988) or 'core rigidities' (Leonard-Barton, 1992). Tacit knowledge in particular may block adaptation to changes in the environment, hinder innovation and lead to the continuation of inferior work practices.

\section{TACIT KNOWLEDGE}

\section{Objective Knowledge}

The customary way of defining tacit knowledge is to compare it to objective knowledge. This knowledge can 'be communicated from its possessor to another person in symbolic form and the recipient of the communication becomes as much "in the know" as the originator" (Winter, 1987, p. 171). This suggests that the concept of objective knowledge can be decomposed into two elements. The first element is about the communicability of objective knowledge: it can be readily 'written down, encoded, explained, or understood' (Sobol and Lei, 1994, p. 170). The second element concerns the possession of objective knowledge. Sobol and Lei (1994) argue that 'such knowledge is not specific or idiosyncratic to the firm or person possessing it' (p. 170). This knowledge can be shared. This definition, or subtle variations of it, is widely used throughout the literature to define objective knowledge. However, despite this agreement about what objective knowledge is, there is an abundance of terms used to refer to it: articulated knowledge (Hedlund, 1994), articulable knowledge (Winter, 1987), explicit knowledge (Nonaka, 1991), verbal knowledge (Corsini, 1987) and declarative knowledge (Kogut and Zander, 1992). It is important to be aware of these various synonyms because it helps us in deciphering and understanding authors' ideas and arguments. Defining objective knowledge is a way of highlighting what tacit knowledge is not. In what follows, we concentrate on what tacit knowledge is.

\section{Tacit Knowledge}

Before outlining the nature of tacit knowledge, it should be noted that a large majority of authors that write about tacit knowledge refer to Polanyi (1962, 1966, 1976) who introduced the concept. Polanyi describes tacit knowledge as follows: 'I shall reconsider human knowledge by starting from the fact that we can know more than we can tell' (1966, p. 4) or we have a 'power to know more than we can tell' (1976, p. 336).

One of the characteristics of tacit knowledge is that it is difficult to write down, to formalize (Nonaka, 1991). People that possess tacit knowledge cannot explain the decision rules that underlie their performance: 'the aim of a skilful perfor- 
mance is achieved by the observance of a set of rules which are not known as such to the person following them' (Polanyi, 1962, p. 49).

Another characteristic of tacit knowledge is that it is personal knowledge. Sternberg (1994) and Nonaka (1991) argue that tacit knowledge has a cognitive dimension, in the sense that it is scripted. For them, tacit knowledge consists of mental models that individuals follow in certain situations. These are deeply embedded in the individuals and tend to be taken for granted. Ravetz (1971) suggests that tacit knowledge becomes so embedded in the individual that it seems entirely natural. This is a reason why it cannot be expressed and why it is attached to the knower.

Another feature of tacit knowledge is that it is practical (Sternberg, 1994) and that it describes a process. If, like some authors (Amit and Shoemaker, 1993; Grant, 1991; Rao, 1994) we were to make a distinction between resources, i.e. inputs into the production process, and capabilities, i.e. processes by which the resources are utilized, rather than use the generic term of 'resource' (meaning both) it would be appropriate to use the term 'capability' rather than 'resource' when referring to tacit knowledge. In this respect, it is similar to know-how (Kogut and Zander, 1992; Nonaka, 1991). Nonaka (1991) argues that know-how may be used as a synonym for tacit knowledge because 'tacit knowledge consists partly of technical skills the kind of informal, hard-to-pin down skills captured in the term "know-how", (p. 98).

Finally tacit knowledge is context specific. It 'is a knowledge typically acquired on the job or in the situation where it is used' (Sternberg, 1994, p. 28), or as Nonaka (1991) puts it, 'tacit knowledge is . . . deeply rooted in action and in an individual's commitment to a specific context - a craft or a profession, a particular technology or product market, or the activities of a work group or team’ (p. 98).

\section{Tacit Knowledge as a Resource}

The resource-based view of the firm examines the link between the internal characteristics of a firm and firm performance (Barney, 1991; Wernerfelt, 1984). Broadly speaking, this means that the resource-based view is concerned with the relationships between a firm's resources and competitive advantage. The view suggests that an organization can be regarded as a bundle of resources and that resources that are simultaneously valuable, rare, imperfectly imitable and imperfectly substitutable (Barney, 1991) are a firm's main source of sustainable competitive advantage. The characteristics we have described above show why tacit knowledge can be argued to be a source of advantage according to the resource-based view: it is unique, imperfectly mobile, imperfectly imitable and non-substitutable.

Because tacit knowledge and skills are deeply ingrained in people or organizations, they are implicit, taken for granted (Nelson and Winter, 1982), and so it becomes difficult for outsiders to imitate or copy them' (Sobol and Lei, 1994, p. 171). Tacit knowledge cannot quickly migrate, i.e. it cannot be transposed to other firms, because the knowledge depends upon specific relationships (between colleagues, customers, etc.) and because 'unlike knowledge of a computer code or a chemical formula, it cannot be a clearly and completely communicated to someone else through words or other symbols' (Badaracco, 1991, p. 82). Tacitness also generates ambiguity because the organization may be unaware of the resources and notably the actions it undertakes that are sources of its competitive 
advantage. In other words, the relation between actions and results is causally ambiguous (Reed and DeFillippi, 1990).

\section{ISSUES IN RESEARGHING TAGIT KNOWLEDGE}

\section{Tacit 'Knowledge'?}

Before dealing with the methodological issues concerning tacit knowledge it is worth noting that there is in the tacit knowledge literature an abundance of synonyms for the term. Hence, for instance, Nelson and Winter (1982) state that tacit knowing is what is ordinarily called skills. Tacit knowledge also refers to know-how (Corsini, 1987; Kogut and Zander, 1992), and Kogut and Zander (1992) also believe that a 'recipe' is comparable to know-how, and hence to tacit knowledge. Tacit knowledge is also referred to as unarticulated, implicit (Spender, 1994), uncodifiable (Hu, 1995) or procedural (in opposition to declarative) knowledge.

Apart from the confusion accruing from the use of these different expressions, employing the word 'knowledge', be it by qualifying it with tacit or implicit or procedural or unarticulated or any other adjective of the same nature, may be inappropriate when dealing with 'tacit knowledge'. The reasons behind this assertion are first, the observation that "when we hear the term "knowledge", we tend to think "science" and "objectivity", (Spender, 1993, p. 246). This means that the term tacit knowledge is a difficult concept to come to terms with because 'tacit', implying subjectivity and unconsciousness, is associated with 'knowledge', implying some degrees of objectivity. Therefore, there is a mismatch, both terms are difficult to reconcile, and one needs to make the effort of thinking beyond the first meaning of knowledge. Secondly, when looking in some detail into the definitions of tacit knowledge the word 'doing' (or other equivalents) commonly occurs. Hence, we have definitions that state that tacit knowledge is practical (Sternberg, 1994), that it is similar to know-how, it is about how to do something rather that knowing what to do (Kogut and Zander, 1992), it is a competence (Badaracco, 1991), it is partly composed of technical skills (Nonaka, 1991), and it is sedimented into work practices (Spender, 1994). This is the second reason why it can be argued that the term 'knowledge' may not be the most pertinent to employ when discussing the concept in relation to the resource-based competitive advantage. Hence, it is here proposed that the expression 'tacit knowledge' be replaced by 'tacit skills', skills implying 'doing'. Drawing the distinction between tacit skills and tacit knowledge helps us make explicit that tacit knowledge is not about 'knowing about', knowing in the abstract, but that it is about action, doing. Tacit knowledge is practical. This clarification should allow us to find some avenue to operationalize the concept. We shall refer to tacit skills in the rest of the paper, with the understanding that this term reflects the concept of tacit knowledge in the context of the resource-based view of the firm.

\section{Methodological Issues}

As indicated earlier, the claim that tacit skills occupy a central role in the development of competitive advantage is widespread. However, despite the attention that has been dedicated to the issue there is little empirical research to support these theoretical developments. 
One of the main reasons why there have been very few attempts to empirically research tacit skills is that it is problematic. Research instruments such as surveys and structured interviews are likely to be inappropriate insofar as individuals cannot be asked to state what they cannot readily articulate. The main challenge that may have to be faced is finding ways of expressing what is, or more correctly what has not been up to now, expressible (Nonaka, 1991). Despite this, we shall try in the next few paragraphs, to set out the premises of a methodology that should allow us to explore tacit skills.

Tracitness and objectivity. Up to now, in line with many authors, we have separated clearly tacit knowledge from objective knowledge. However the two types are not completely distinct. In his work, Polanyi (1966) explains that scientific knowledge starts with tacit knowledge. For him objective and tacit knowledge are not separate, and tacit knowledge is prior to explicit knowledge. He argues that 'things of which we are focally aware can be explicitly identified; but no knowledge can be wholly explicit.... Hence tacit knowledge is more fundamental than explicit knowing. We can know more than we can tell and we can tell nothing without relying on our awareness of things we may not be able to tell' (p. 4).

This argument is not unique to Polanyi (1966). Ravetz (1971) similarly argues that scientific knowledge 'depends on a personal knowledge of particular things, and on subtle judgements of their properties' (p. 109); Collins (1974) that 'all types of knowledge, however pure, consist, in part, of tacit rules which may be impossible to formulate in principle' (p. 167); and Gelwick (1977) that 'science is pursued for its bearing on reality, but reality is not explicitly definable. It is one of the paradoxes of our knowledge that we accept science because we think it gives a truer account of reality, yet this account could be false' (p. 85). Gephart (1988), in his work on ethnostatistics also highlights that researchers 'should not expect or pretend that statistical rules are explicit' (p. 64). They 'should expect to undertake ad hoc and post hoc interpretations of rules' (p. 64).

Despite these arguments, in much of the literature, both types of knowledge are argued to be two distinct entities. This may be due to our positivist heritage. As suggested by Czarniawska (1998), referring to Lyotard (1986), 'the legitimacy of scientific knowledge in its modern and western meanings depends on its sharp differentiation from the common sense, everyday knowledge of ordinary people the narrative knowledge that tells of human projects and their consequences as they unfold over time' (p. 3). Emphasizing the differences also facilitates the categorization of the two knowledge types 'which would otherwise appear to be seamless, endlessly interacting' (Spender, 1994, p. 394).

Degree of tacitness. The definition of 'tacit' skills may encompass a range of different degrees of tacitness (figure 1). As two anchor points we can have 'explicit skills', i.e. skills that can easily be communicated, codified and shared, and, tacit skills that are totally unavailable, that are not accessible to the knowers because they are too deeply ingrained.

In between these two points, one can find at least two other degrees of tacitness: tacit skills that are unarticulated but that could be articulated readily if organizational members were simply asked the question: how do you do that? These tacit skills, if we were to follow Berry's work on expert's knowledge (1987) are tacit but have been acquired explicitly. They have become tacit through time. In this 


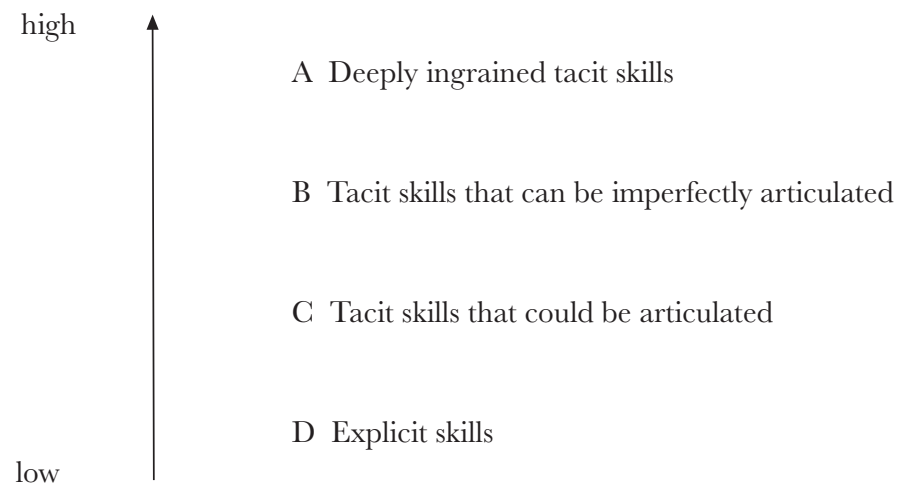

Figure 1. Degree of tacitness

case the skills are tacit simply because nobody has asked the right question, people never thought of what they were doing, they never asked themselves what they were doing, and nobody else ever asked it either.

There are also tacit skills that could be accessed but that cannot be expressed through the normal use of words. They could however be articulated differently, maybe through the use of metaphors and storytelling.

Because of the lack of empirical knowledge on tacit skills, operationalizing the 'most tacit' tacit skills is unlikely to be a realistic endeavour. However trying to operationalize tacit skills that are not yet articulated but could be accessed through asking the right question or expressed through other means than 'formal words' may be achievable and may allow researchers and managers themselves to better understand how their firms achieve success. Hence we shall concentrate our attention on $\mathrm{B}$ and $\mathrm{C}$ in figure 1.

Eliciting tacit skills: philosophical stance. As mentioned earlier there have been very few attempts to empirically research tacit skills and hence there is no 'ready' methodology for their study. In what follows we suggest how such research may be possible. We propose a methodology, based on techniques that have been argued in social sciences to be suitable for studying intangible phenomena, which we believe to be applicable to tacit skills. Before embarking on the methodology we would like to briefly comment on our philosophical stance. Based on our previous discussion on tacitness, objectivity and the point that tacit and actually all knowledge depends on the knower (a point which is clearly not in line with the Cartesian split between subject and object, and the knower and the known) and is context specific (which implies that tacit knowledge is not generalizable), we adopt in this paper a social constructivist position (Berger and Luckmann, 1966). This means that we believe that the world is socially constructed. We acknowledge that people construct their world but they can nevertheless experience it as something more than a human construction. This implies that meaning cannot be 'objective' in the positivist sense, meaning is constructed by people. Social constructivism is not unique in being concerned with individuals as constructor of meaning. As argued by Schwandt (1997) and Crotty (1998) it has great affinities with ethnomethodology (Garfinkel, 1967), existentialism (Lyotard, 1986) or phenomenology (Schultz, 1967). These all emphasize the actor's definition of the situation, they all contend 
that 'all knowledge and therefore all meaningful reality as such, is contingent upon human practices, being constructed in and out of interaction between human beings and their world, and developed and transmitted within an essentially social context' (Crotty, 1998, p. 42). This means that 'experiences do not constitute a sphere of subjective reality separate from, and in contrast to, the objective realm of the external world - as Descartes split between mind and body, and thereby mind and world, would lead us to imagine' (Crotty, 1998, p. 45).

This philosophical stance means that we need to find a method that would allow us to capture the constructed reality of individuals which allows them to make sense of the world around them. We are interested in the reflection of what they make of what is there. In short we take the position that 'if men define situations as real, these are real in their consequences' (Thomas and Thomas, 1928, p. 572).

\section{RESEARGHING TAGIT SKILLS: PROPOSED METHOD}

In the next few pages, we set out the methodology we propose could be used to empirically research tacit skills. We suggest that causal mapping is a simple but yet powerful technique that can help us in surfacing tacit skills. We begin by describing the research proposal we designed based on our review of the research methods literature on intangible phenomena, then we proceed by giving an example of how our method can be applied.

\section{Cognitive Maps}

Cognitive maps are ways of representing individuals' views of reality (Eden et al., 1981). They 'are intended to relate to the way in which a person "makes sense of" and explains the world around him' (Eden, 1990, p. 37). They are the representation of an individual's personal knowledge, of an individual's own experience (Weick and Bougon, 1986). 'The process of map construction and the use of the map is intended to facilitate the elaboration and exploration by the client of his own belief and value system in relation to particular issues' (Eden et al., 1981, p. 41).

There are different types of cognitive map (see Huff, 1990), one being the cause or causal map: 'a cause map is a form of cognitive map that incorporates concepts tied together by causality relations' (Weick and Bougon, 1986, p. 106). It is a graphic representation 'which consists of nodes and arrows that link them' (Laukannen, 1994, p. 323). The nodes are the constructs that the person believes important and the arrows show the relationships between the constructs.

\section{Causal Maps}

Causal mapping is likely to be a pertinent technique to use in researching tacit skills because causal mapping allows to focus on action (Huff, 1990). When assessing its appropriateness in this context, we should restate that tacit skills are about doing things and because, as Jenkins (1995) noted, 'causality provides a potentially higher level of procedural knowledge (how it works, and how to do it) than other sets of relationships' (p. 53), we believe that causal maps are likely to be appropriate for studying tacit skills.

Another reason for using such maps is that the question, 'are tacit skills a source of competitive advantage?' is by nature a causal question. 
Furthermore, causal maps can be particularly useful for eliciting factors that are context dependent, as tacit skills are, because 'by virtue of the time spent in a particular department or function, managers develop a viewpoint that is consistent with the activities and goals of that department or particular function' (Walsh, 1988, p. 857, emphasis added) and as Bougon et al. (1977) point out, this is partly stored in the minds of managers in the form of cause maps. One of the main advantages of using such a technique is that maps 'place concepts in relation to one another, . . . they impose structure on vague situations' (Weick and Bougon, 1986, p. 107). Cause maps are therefore a way of ordering and analysing something that is 'fuzzy'. These maps are also useful in eliciting tacit skills because they allow us to study issues at a micro-level; they can also represent multiple explanations and consequences, and show interrelationships between factors and potential dilemmas (Eden and Ackermann, 1998).

We are proposing to use causal maps as a technique that would allow us to elicit tacit skills. We adopt Eden's (1992) view that 'the only reasonable claim that can be made of cognitive maps as an artefact . . . is that . . . they may represent subjective data more meaningfully than other models' (p. 262). Hence, here cause maps are to be used as 'tools for reflective thinking and problem solving' (Eden et al., 1992, p. 321).

There are several ways of deriving so-called group or collective maps. They can be an average of individual maps, a composite of individual maps (Weick and Bougon, 1986) or they can be derived from group discussion (Nelson and Mathews, 1991). However, because a group map may encompass more that the common content of the individual maps (Langfield-Smith, 1992), we propose that building the causal map should be a group activity. By looking at the views of others and reconsidering their own views, group members should be able to reflect on their own and others' behaviours in the light of the group level interaction and discussion. Moreover a group map 'as a visual interactive model, acts in the form of a ... transitional object, that encourages dialogues' (Eden and Ackermann, 1998, p. 71). This approach could be a convincing element when appealing for organizations to participate in research, as 'the process of constructing a consensus around causal factors influencing the organisation can be a useful diagnostic exercise' for the organization (Nelson and Mathews, 1991, p. 381).

The group discussion could take the format of focus groups. To discover which tacit skills are valuable and to follow the resource-based view of the firm's line of questioning 'is $\mathrm{X}$ a source of sustainable competitive advantage', the discussion should focus on a more straightforward, if less precise question like: 'what makes your organization successful?' Respondents could be asked to express the relationships between the constructs, which variable influences which other variables, etc. The relations could be established not only on what the participants 'know' but also in their attitudes, reactions, feelings etc. The advantage of a focus group format is that 'the inherent group dynamics tend to yield insights that ordinarily are not obtainable from individual interviews' (Schiffman and Kanuk, 1991, p. 52).

\section{Eliciting Tacit Skills: the Process}

We believe that the causal mapping system should be powerful in revealing tacit skills because the process is about continuously asking the respondents to reflect on their behaviours, on what they do. They would ordinarily not do so. During the mapping, they are pressed to explain what they do and in that process they 
reveal to themselves aspects of their behaviour that up to that point were tacit (in terms of degrees $\mathrm{C}$ and possibly $\mathrm{B}$ of tacitness in figure 1). The in-depth probing that allows the map to develop taps the skills that go unspoken in the organization. While mapping, the researcher should be able to catch instances where individuals say things such as 'Oh yes, that's right', 'Aha! I hadn't realized that'. The 'oh, yes' experience suggests that something that was tacit has just been made explicit by an individual. This is also a sign that the session is going well and that managers are gaining insights from the session and are becoming aware of their, up-to-now tacit, skills.

Starting the causal map. As mentioned earlier we propose to start with the broad question: what causes success in the organization? The first few answers are likely to be well-known causes for that success. They are likely to be general and of common knowledge. We describe how we suggest starting the map in the next few paragraphs.

There are several ways of building a map. For instance, Walsh (1988) uses a predefined list; Axelrod (1976) derives the constructs from texts and Markóczy and Goldberg (1995) from interviews. As we are looking at taken for granted tacit knowledge, prescribed checklists or structured interviews are likely to be inappropriate. There is a need for 'creat[ing] a situation in which cognitive maps can emerge as fully as possible with a minimum of influence' (Bougon, 1983, p. 182), i.e. we should 'avoid suggesting anything to the individual that might become part of an eventual cognitive map' (Cossette and Audet, 1992, p. 332). So we believe that the map should ideally be built without predetermined constructs. The constructs should be established during the mapping session itself.

However, we are aware that starting a causal mapping session from scratch could be time consuming and hence we believe that preliminary interviews could be a way to elicit constructs that could be used as a basis for the maps. From the literature we concluded that two different methods could be appropriate to elicit those constructs. They could be uncovered through self-Qinterviews, a technique that minimizes the influence of the researcher (Bougon, 1983) or through semi-structured interviews, with storytelling. We propose that each participant should be interviewed once. Half of the group could be interviewed using one technique and half using the other one. Both methods are detailed in what follows. The motive for using two separate methods is to 'make sure that the ground is well covered' (Markóczy and Goldberg, 1995, p. 310). The interviews to elicit the constructs that would be used to start the causal map should be carried out on an individual basis. These interviews should provide an opportunity to establish rapport with the participants. This is paramount as 'close rapport with respondents opens doors to more informed research' (Fontana and Frey, 1994, p. 367).

Self-Q. The self-Q technique is a non-directive mapping technique developed by Bougon (1983). It is a self-interviewing technique that draws on the respondent's account of his/her beliefs to generate constructs. The reason why tacit skills could be elicited through self-Q questioning is best given by this quote: 'in self- $Q$ interviews, participants essentially interview themselves. The first key idea is that participants are the experts on the personal knowledge that guides their social behaviour. The second key idea is that participants formulate their questions on the basis of their own personal knowledge ... and on the basis of their own 
thinking ... about the situation they are questioning' (Bougon et al., 1989, pp. 328-9). Bougon et al. (1989) also assert that with the self-interviewing technique 'the events, objects, and concepts [the participants] use to express their questions ... reveal their tacit and explicit knowledge' (p. 329).

As mentioned previously this technique could be applied to elicit the constructs that could be used to start building the group cause map. The technique involves 'people ask[ing] themselves questions about whatever topic is being mapped and the concepts are then extracted from the questions' (Weick and Bougon, 1986, p. 115). Here the questioning is to be focused on the respondents' views about what they do that makes the organization successful. Practically, 'the self-Q technique uses a framing statement and a . . diagram. The framing statement is read by participants and is intended to set the stage for self-questioning and to provide the subject with enough information to begin the self-questioning process. . . . The diagram is intended to be used by participants to cue themselves to ask additional questions' (Sheetz et al., 1994, p. 37). This technique is appealing because it lowers the participants' resistance to respond: 'people are not practised in defending against questions that they ask themselves and over which they have control. Furthermore, since the person is asking questions rather than making assertions, the questions themselves seem harmless' (Weick and Bougon, 1986, p. 115). Another benefit of this technique is that the researcher does not hinder the production of constructs by his/her lack of knowledge of the organization under observation. The fact that 'often a researcher . . . does not really know enough to ask the right questions' (Bougon et al., 1989, p. 353) is not an issue when using the self-questioning technique.

Semi-structured interviews. The second method that could be used to start uncovering constructs is semi-structured interviews. The interviews would be semistructured in the sense that their purpose and structure is pre-determined: for example we want to know what the causes of success are, and we want participants to give examples, to tell stories about this success.

We believe that it would be useful to encourage the interviewees to tell stories because 'stories are one of the many forms of implicit communication used in organisational contexts' (Martin, 1982, p. 257). People 'manage the collective memory of the organisation through storytelling' (Boje, 1991b, p. 9). Martin (1982) explains that stories are used in organizations to "explain "how things are done around here", (p. 256). It is also an appropriate device for studying tacit skills because people frame their experience in stories (Wilkins and Thompson, 1991). Moreover, 'stories are contextually embedded' (Boje, 1991a, p. 109), they 'can reflect the complex social web within which work takes place' (Brown and Duguid, 1991, p. 44). In other words, through storytelling, participants can express what is done in the organization, and hence some tacit skills may be uncovered. This means that through stories people say more that they would normally; 'stories permit researchers to examine perceptions that are often filtered, denied, or not in the subjects' consciousness during traditional interviews' (Hansen and Kahnweiler, 1993, p. 1394).

The stories could be generated through interviews with the participants being asked to tell maybe two stories, one positive and one negative, concerning what has in the past caused organizational failure and organizational success (this is based on the critical incident technique developed by Flanagan (1954)). As 
recommended by Ford and Wood (1992) the interviews should, if possible, take place in the participants' organization as the familiar surroundings can serve as cues.

Metaphors. Martin (1982) argues that both stories and metaphors can serve to transmit tacit knowledge. Metaphors ${ }^{[1]}$ are interesting as a way of eliciting tacit skills for a variety of reasons. Metaphors may be of help in attempting to elicit tacit skills because metaphorical language is argued 'to be employed to give to tacit knowledge voice' (Munby, 1986, p. 198). It is so because 'metaphors can communicate meaning when no explicit language is available, especially in regard to complex ambiguous experience' (Srivastava and Barrett, 1988, p. 60).

Among the reasons behind the claim that metaphors can help express what is not easily articulable are that metaphors can generate new meaning, that they can 'render vague and abstract ideas concrete' (Sackmann, 1989, p. 482) and that because they allow different ways of thinking, people may be able to explain complex organizational phenomena (Tsoukas, 1991). Another reason is that they 'transmit an entire story visually using one image' (Sackmann, 1989, p. 468). This idea of image is central in understanding the argument concerning the articulation of tacit knowledge through metaphors. Because metaphors are vivid images, they may substitute for a large number of words (Sackmann, 1989) and they are 'useful in coping with large amount of data' (Hill and Levenhagen, 1995, p. 1068). Images also allow us to speak about a process because they are not discrete. This matters as tacit skills are capabilities, they are a process (they are about how to do things).

The procedural aspect of tacit skills is a factor in why it is difficult to communicate it through words. This is explained by Ortony (1975): 'language [is a] discrete symbols system ... words partition experiences' (Ortony, 1975, p. 46), however, 'experience does not arrive in little discrete packets, but flows, leading us imperceptibly from one state to another' (Ortony, 1975, p. 46). 'Thus the task we have to perform in communication is to convey what is usually some kind of continuum by using discrete symbols. It would not be surprising if discrete symbol systems were incapable of literally capturing every conceivable aspect of an object, event or experience that one might wish to describe... This deficiency is filled by metaphor' (Ortony, 1975, p. 46). Metaphors are a means of capturing the continuous flow of experience, hence they can be a means of capturing tacit knowledge. 'They allow the transfer of concrete bands of experience whereas literal discourse segments experiences' (Tsoukas, 1991, p. 581). 'One can say through metaphor what cannot be said in discrete, literal terms, especially when words are not available or do not exist' (Srivastava and Barrett, 1988, p. 37).

All the above suggests that it is worth considering metaphors when attempting to elicit tacit skills. However, capturing metaphors may not be trouble free. One of the problems is obviously to make sure that a metaphor is not used when more direct language could easily be available. It is necessary to ensure that the metaphor is employed where no appropriate words are accessible. One way of making sure that a metaphor is used in such a manner is by asking the individual to express his/her metaphor in another way. If another metaphor is used rather than literal expressions, then one may be inclined to think that the use of metaphor is appropriate. The second problem is that every individual may not be ready or able to use metaphors during a discussion. 
The mapping process. The interviews we have just described, whether based on selfQ, or semi-structured interviews, should have allowed the researcher to better know the participants, raise their confidence in the process and of course should have elicited a few 'success' factors. This being done the tacit skill elicitation process can begin in earnest. The map can start with 'success' and these previously revealed factors. The goal of the mapping is now to find the reasons for the reasons for success. The questions that can help the participants to do so could be, for instance: how does that happen? What causes that? Who is involved? What influences that? By answering the questions the participants can start eliciting more particular, precise reasons for success. This is a digging process. The best image to describe the process is maybe the 'onion' metaphor. Causal mapping is like peeling an onion. By peeling layer after layer of the reasons for success participants get to the detail, the less explicit causes for success. Causes they could not have readily surfaced without prompting and probing. It is important throughout the session to insist that we are only interested in what they are currently doing, even if it is perceived to be trivial or irrelevant, and not in what they believe they should be doing, an understandable concern of organizational members.

When the process moves from the explicit reasons for success, and where the participants have to reflect on what they never usually think about, the flow of factors is likely to slow down. In this case we suggest that the researchers should encourage the participants to think of examples of how they perform the factor they have just elicited, or tell stories about the factor or use metaphors to explain how the factor words, as, as we explained previously, these techniques have been argued to help express the inexpressible.

Throughout the mapping participants should be encouraged to speak about what they do and the factors should be written as actions, if possible, rather than abstract statements, as tacit skills are about doing and not verbalizing what is done. It is not about 'knowing about' or reciprocally 'not knowing about'. Asking participants to use verbs and 'I' could be a way of making sure they are discussing what they are doing.

The map will stop when the respondents, despite being pressed for more examples and encouraged to say more, cannot reveal more factors.

Figure 2 is a summary of the causal mapping process that could help in eliciting tacit skills ( $B$ and C from figure 1 ) that we have just described. It is followed by a short example of part of a map (figure 3) that was built with the top management team of a financial services organization operating mainly within the charity sector.

The practical benefit of the mapping process should be that it can help a management team identify critical skills in their organization. The skills performed in the organization could be categorized, and the implications for senior management might be as follows:

(1) Skills that are explicit are skills that are unlikely to be source of sustainable competitive advantage because they are easy to imitate and transfer across organizations. This does not mean that they are not valuable. They may well be essential for success. Those skills may be necessary for managers to possess if their organization wants to be a player in an industry. These skills may be order-qualifying, they are not differential abilities. These skills are 
1. Preliminary interviews about what causes success in the organization to elicit constructs to start the map (A, B and $\mathrm{C}$ )

2. Set up the map with the preliminary constructs as starting points

3. Begin the mapping process with questions such as: What causes that? How does it happen?

4. If the flow of constructs stops, ask questions such as: Could you give us an example of how that happened? Could you tell us a story?

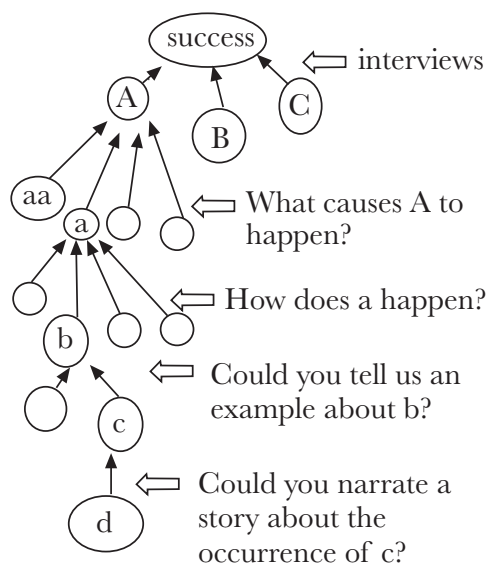

Figure 2. Researching tacit skills: a summary of the proposed method

easy to control as they are well known. Managers may decide to improve on them, change them or abandon them.

(2) Skills that are tacit but that could be articulated if managers were pushed to do so are skills that are likely to be unique and context specific. These skills are differential abilities. They potentially contribute to, for example, order-winning product features. Once surfaced these skills may be transferable within the same context or may be only imperfectly transferable, as two contexts are rarely ever similar. Managers may decide to transmit these skills to other parts of the organization. Once elicited these skills can be worked on, they can be managed.

(3) Tacit skills that remain unconscious, that managers cannot become aware of could be differential activities that confer advantage. They are unique and not imitable. They cannot be transferred even within the same organization as managers are not aware of them. These skills cannot be 'managed' as they are deeply ingrained within individuals.

\section{Observation}

The causal mapping exercise we suggest is very much based on ethnographic techniques and therefore complementing them with participant observation may be a way of enriching the data obtained and improving the validity of the findings (Pettigrew, 1973).

Tacit skills are picked up by 'osmosis' (Spender, 1996). They develop over time (Leonard-Barton, 1992), are acquired through experience (Ravetz, 1971) and are acquired where used (Wright, 1994). For these reasons, one can easily understand why Pavitt (1991) suggested that the most effective way of learning tacit skills was through personal contact and discussions. Pursuing the same track, Sobol and Lei (1994) declared that 'learning tacit knowledge and skills requires continuous dayto-day contact with the person, team or organisation possessing such knowledge through an apprentice-like relationship where the skills are directly observed and practice' (p. 171). 
Map

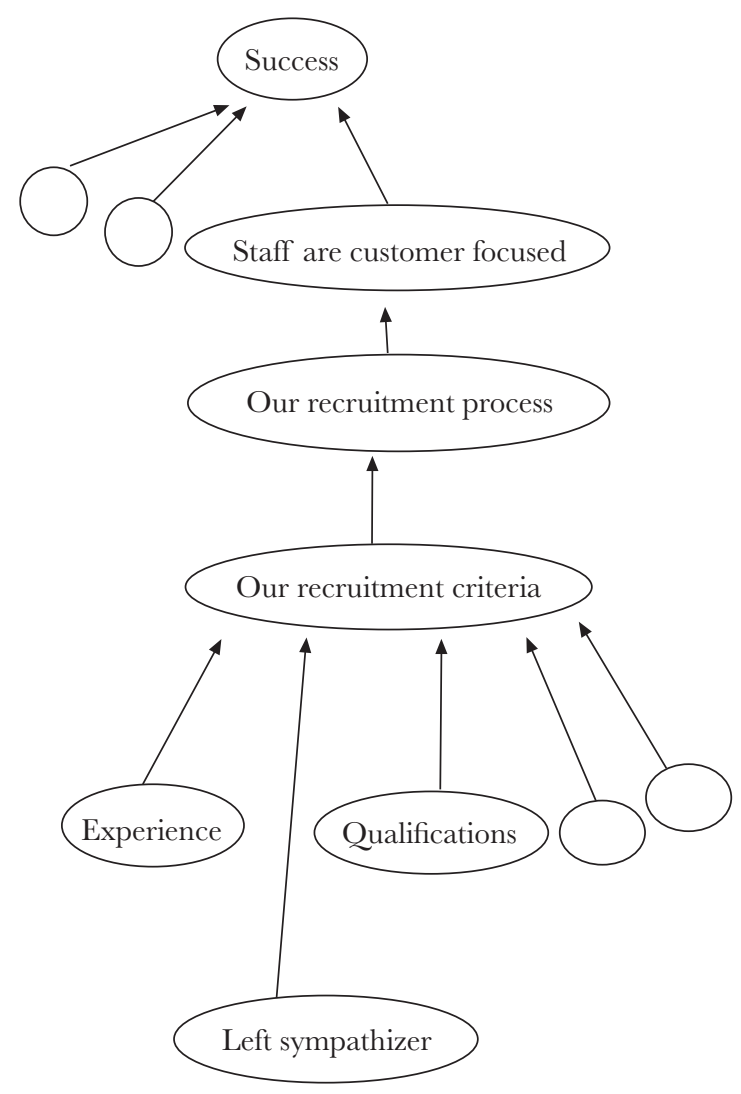

The mapping process started with the question:'What causes success in your organization?' The question was introduced during the preliminary interviews.

This was one of the answers given during the interviews. The mapping session started from here. We asked 'Why are the staff customer focused? What causes this?'

One answer was: 'It is because of how we recruit our staff'. We then asked: 'How do you do that, can you explain your process?'

The answer was: 'It is because we have certain criteria'. We then asked: 'Could you list them?'

Here is a sample of the answers. We then said: 'Every company uses the same criteria, they are not unique to you. Let us assume that I was a candidate and think back to your recent interviews. Are there any special things you do? Questions you ask?"

The answer was: 'let's see, ... after I've covered the usual ground,...oh yes, ...I usually try to find out something about their politics'. We then asked: 'Why?'.The answer was: 'Well, most of our customers are on the left and if our staff are similar to our customers they are more likely to have some empathy with them'.

Figure 3. Extract from a financial services company map

All this suggests that research into tacit skills could be conducted through observation and immersion in an organization, notably because: 'observation is justified if no language or vocabulary is available with which to describe that native experience in which the ethnographer is interested' (Werner and Schoepfle, 1987, p. 266). Participant observation allows us to learn about the context. However, as the context is changed by the inquiry process, observation as a method implies the need to spend quite some time in the organization so that the disturbing effect decays. Another option is to follow Louis and Bartunek's (1992) suggestion of having research teams composed of both 'insiders' and 'outsiders'. They suggest 
that such teams are useful when the research goal is 'to explicate core beliefs and/or assumptions held by a member of a setting' (p. 108).

Observation and causal mapping techniques should complement each other and should allow the capture of a 'rich' picture of the organization under study.

Before concluding we would like to remark that, even if possible, we believe that direct observation of skilful performances is likely to be difficult in researching tacit skills in relation to the resource-based view of the firm. It is difficult to be everywhere (a large team would be required to watch many individuals in the organization). The researchers may not necessarily be able to understand the significance of the activities carried out. Finally the observation may be so limited that it may be difficult to relate what is being observed to organizational level success. The causal mapping method that we described previously is an indirect way of surfacing tacit skills. It will be fragmented, not comprehensive, partial and biased but it should provide some insights to both participants and researchers into tacit skills and organizational success.

\section{CONGLUSION}

We have explained in this paper that it is widely acknowledged that tacit knowledge can lie at the base of sustainable competitive advantage. This is so because tacit knowledge can be a resource that allows a firm to perform better than its competitors, it is a 'differential ability' (Conner, 1994): it is heterogeneous across firms, unique, imperfectly immobile and imperfectly imitable. This argument, though, has remained largely theoretical. There is no empirical evidence to support the theory. One of the reasons for the lack of field research is that the concept of tacit knowledge is difficult to operationalize.

In this paper we have explored tacit knowledge and ascertained that, for the purpose of exploring its role as a 'resource', the concept should be replaced with the term tacit skills. We explained that tacit skills are taken-for-granted, are practical and context specific and should be studied within an interpretivist framework. We also suggested that there were different degrees of tacitness. Skills may be unarticulable because they are deeply ingrained in the unconscious, they could also be only imperfectly articulable, or articulable, if one could find the right trigger to allow the individuals to express them. We suggested that, considering our lack of knowledge on tacit skills, we would concentrate on those skills that are not articulated but that yet could be, even if imperfectly.

We then proposed an avenue for empirical research. We suggested that causal mapping could be a useful method to elicit tacit skills. This technique allows the participants to reflect on what they are doing. By continually asking them what they do that causes success they uncover skills that they would not normally talk about. The process is facilitated by encouraging the participants to tell stories and employ metaphors.

Before concluding the paper we just would like to acknowledge some of the limitations of our proposals. Clearly, one cannot establish a unique and direct link between tacit skills and competitive advantage. There is not a single factor that causes performance, tacit skills may be just one of many. We also would like to point out that it is likely to be easier to study tacit skills in organizations that operate 
in stable environments. In face of environmental changes tacit skills may become obsolete (Brumagin, 1994). To cope with changing conditions, individuals are often pushed to modify their behaviours, give up processes and implement new ones, hence risking the loss of their skills. Finally we would like to raise the issue of access into organizations to pursue such research. The principal reason why tacit skills has been argued to be a source of sustainable advantage is because of its immobility and inimitability. By surfacing them organizations take the risk of making them accessible and hence losing their advantage. However this argument can be reversed by saying that if an organization is aware of the real source of its superiority it can attempt to protect it and nurture it.

Tacit knowledge is an issue that calls for action. The idea that it is valuable needs to be empirically researched. We hope that this paper will provide the basis for fruitful discussion and will act as a trigger for field studies.

\section{NOTE}

[1] 'Metaphor involves, or is, the transfer of meaning' (Ortony, 1975, p. 45). It involves the transfer of information from a relatively familiar domain (usually called the vehicle or the base domain) to a relatively unknown domain, usually called the tenor, the topic or the target domain (Tsoukas, 1991). In other words, metaphors allow inferences to be made about one of the things, usually that about which we know least, on the basis of what we know about the other' (Harré, 1984, p. 172). This means that the meaning of the vehicle is applied to the topic, the vehicle is used metaphorically, there is a comparison between both terms. The metaphor provides 'information about the structure, content, and meaning of the particular situation' (Sackmann, 1989, p. 465). It may be worth noting that sometimes a distinction is made between metaphors (the general term), similes (that compare one item with another, A is like B) and analogies (that focus on the relationships between items, $\mathrm{A}$ is to B as $\mathrm{C}$ is to D). However, in most studies no differentiations are made (Ortony, 1975; Sackmann, 1989).

\section{REFERENGES}

Amit, R. and Shoemaker, P. J. H. (1993). 'Strategic assets and organizational rents'. Strategic Management Fournal, 14, 33-46.

Axelrod, R. M. (1976). The Structure of Decisions: Cognitive Maps of Political Elites. Princeton, NJ: Princeton University Press.

Badaracco, J. L. (1991). The Knowledge Link. Boston: Harvard Business School Press.

BARNEY, J. B. (1991). 'Firm resources and sustained competitive advantage'. Fournal of Management, 17, 1, 99-120.

Berger, P. and Luckmann, T. (1966). The Social Construction of Reality. New York: Doubleday. Berry, D. C. (1987). 'The problem of implicit knowledge'. Expert Systems, 4, 3, 144-51.

Boje, D. M. (1991a). 'The storytelling organization: a study of story performance in an office supply firm'. Administrative Science Quarterly, 36, 106-26.

Boje, D. M. (1991b). 'Consulting and change in storytelling organization'. Fournal of Organizational Change Management, 4, 3, 7-17.

Bougon, M. G. (1983). 'Uncovering cognitive maps'. In Morgan, G. (Ed.), Beyond Method. Beverly Hills: Sage, 173-88.

Bougon, M., Weick, K. and Binkhorst, D. (1977). 'Cognitions in organizations: an analysis of the Utrecht jazz orchestra'. Administrative Science Quarterly, 22, 606-39. 
Bougon, M., Baird, N., Komocar, J. M. and Ross, W. (1989). 'Identifying strategic loops: the self-Q interviews'. In Huff, A. S. (Ed.), Managing Strategic Thought. Chichester: John Wiley, 327-54.

Brown, J. S. and Duguid, P. (1991). 'Organizational learning and communities-ofpractice: toward a unified view of working, learning and innovation'. Organization Science, 2, 1, 40-57.

Brumagin, A. L. (1994). 'A hierarchy of corporate resources'. In Shrivastava, P., Huff, A. and Dutton, J. (Eds), Advances in Strategic Management, 10. A., New York: Jai Press, 81-112.

Collins, H. M. (1974). 'The TEA set: tacit knowledge and scientific networks'. Science Studies, 4, 165-86.

Conner, K. R. (1994). 'The resource-based challenge to the industry-structure perspective'. Best Paper Proceedings, Annual Meeting of the Academy of Management, Dallas.

Corsini, R. (1987). Concise Encyclopedia of Psychology. New York: Wiley.

Cossette, P. and Audet, M. (1992). 'Mapping an idiosyncratic schema'. Journal of Management Studies, 29, 3, 325-47.

Crotty, M. (1998). The Foundations of Social Research. London: Sage.

Czarniaswska, B. (1998). A Narrative Approach to Organization Studies. London: Sage.

Eden, C. (1990). 'Strategic thinking with computers'. Long Range Planning, 23, 6, 35-43.

Eden, C. (1992). 'On the nature of cognitive maps'. Journal of Management Studies, 29, 3, 261-5.

Eden, C. and Ackermann, F. (1998). Making Strategy. London: Sage.

Eden, G., Jones, S., Sims, D. and Smithin, T. (1981). 'The intersubjectivity of issues and issues of intersubjectivity'. Fournal of Management Studies, 18, 1, 37-47.

Eden, C., Ackermann, F. and Cropper, S. (1992). 'The analysis of cause maps'. Journal of Management Studies, 29, 3, 309-24.

Flanagan, J. C. (1954). 'The critical incident technique'. Psychological Bulletin, 51, 327-58.

Fontana, P. A. and Frey, J. H. (1994). 'Interviewing: the art of science'. In Denzin, N. K. and Lincoln, Y. S. (Eds), Handbook of Qualitative Research. Thousand Oaks: Sage, 361-76.

Ford, J. M. and Wood, L. E. (1992). 'Structuring and documenting interactions with subject-matter experts'. Performance Improvement Quarterly, 5, 1, 2-24.

Garfinkel, H. (1967). Studies in Ethnomethodology. Englewood Cliffs, NJ: Prentice-Hall.

Gelwick, R. (1977). The Way of Discovery. Oxford: Oxford University Press.

Gephart, R. P. (1988). Ethnostatistics: Qualitative Foundations for Quantitative Research. Newbury Park: Sage.

Grant, R. M. (1991). 'The resource-based theory of competitive advantage: implications for strategy formulation'. California Management Review, 33, 3, 114-35.

Grant, R. M. (1993). 'Organizational capabilities within a knowledge-based view of the firm'. Paper presented at the Annual Meeting of the Academy of Management, Atlanta, Georgia.

Hansen, G. D. and Kahnweiler, W. M. (1993). 'Storytelling: an instrument for understanding the dynamics of corporate relationships'. Human Relations, 46, 12, 1391409.

Harré, R. (1984). The Philosophies of Science. Oxford: Oxford University Press.

Hedlund, G. (1994). 'A model of knowledge management and the N-form corporation'. Strategic Management fournal, 15, 73-90.

Hill, R. C. and Levenhagen, M. (1995). 'Metaphors and mental models: sensemaking and sensegiving in innovative and entrepreneurial activities'. Journal of Management, 21, 6, 1057-74.

Hu, Y. S. (1995). 'The international transferability of the firm's advantages'. California Management Review, 37, 4, 73-88.

Huff, A. S. (1990). 'Mapping strategic thought'. In Huff, A. S. (Ed.), Mapping Strategic Thought. Chichester: John Wiley, 11-49. 
Jenkins, M. (1995). 'Subjective Strategies for Small Business Growth: an Evaluation of the Causal Maps of Small Independent Retailers'. Unpublished PhD dissertation, Cranfield SOM.

Jensen, A. R. (1993). 'Test validity: g versus "tacit knowledge"'. Current Directions in Psychological Science, 1, 9-10.

Kogut, B. and Zander, U. (1992). 'Knowledge of the firm, combinative capabilities, and the replication of technology'. Organisation Science, 3, 383-96.

Langfield-Smith, K. (1992). 'Exploring the need for a shared map'. Fournal of Management Studies, 29, 3, 349-68.

Laukannen, M. (1994). 'Comparative cause mapping of organizational cognitions'. Organization Science, 5, 3, 322-43.

Leonard-Barton, D. (1992). 'Core capabilities and core rigidities: a paradox in managing new product development'. Strategic Management fournal, 13, 111-26.

Levitt, B. and March, J. G. (1988). 'Organizational learning'. Annual Review of Sociology, 14, 319-40.

Louis, M. R. and Bartunek, J. M. (1992). 'Insider/outsider research teams: collaboration across diverse perspectives'. Fournal of Management Inquiry, 1, 2, 101-10.

Lyotard, J. F. (1986). The Postmodern Condition. A Report on Knowledge. Manchester: Manchester University Press (originally first published in 1979).

Markóczy, L. and Goldberg, J. (1995). 'A method for eliciting and comparing causal maps'. Journal of Management, 21, 2, 305-33.

Martin, J. (1982). 'Stories and scripts in organizational settings'. In Hastorf, A. H. and Isen, A. M. (Eds), Cognitive Social Psychology. New York: Elsevier, 255-305.

Munby, H. (1986). 'Metaphor is the thinking of teachers: an exploratory study'. Journal of Curriculum Studies, 18, 2, 197-209.

Nelson, R. E. and Mathews, K. M. (1991). 'Cause maps and social network analysis in organizational diagnosis'. Fournal of Applied Behavioral Science, 27, 379-97.

Nelson, R. R. and Winter, S. G. (1982). An Evolutionary Theory of Economic Change. Cambridge, MA: The Belknap Press.

Nonaka, I. (1991). 'The knowledge-creating company'. Harvard Business Review, 69, 6, 96-104.

Ortony, A. (1975). 'Why metaphors are necessary and not just nice'. Educational Theory, 25, 1, 45-53.

Pavitt, K. (1991). 'Key characteristics of the large innovating firm'. British fournal of Management, 2, 41-50.

Peteraf, M. A. (1993). 'The cornerstone of competitive advantage: a resource-based view'. Strategic Management fournal, 14, 179-91.

Pettigrew, A. M. (1973). The Politics of Organizational Decision Making. London: Tavistock.

Polanyi, M. (1962). Personal Knowledge, Towards a Post Critical Philosophy. London: Routledge and Kegan Paul.

Polanyi, M. (1966). The Tacit Dimension. New York: Doubleday \& Co.

Polanyi, M. (1976). 'Tacit knowing'. In Marx, M. H. and Goodson, F. E. (Eds), Theories in Contemporary Psychology, 2nd edition. New York: Macmillan, 330-44.

RAo, H. (1994). 'The social construction of reputation: certification contests, legitimation, and the survival of organizations in the American automobile industry: 1895-1912'. Strategic Management Fournal, 15, 29-44.

Ravetz, J. R. (1971). Scientific Knowledge and its Social Problems. Oxford: Clarendon Press.

Reed, R. and DeFillipi, R. J. (1990). 'Causal ambiguity, barriers to imitation and sustainable competitive advantage'. Academy of Management Review, 15, 1, 88-102.

Sackmann, S. (1989). 'The role of metaphors in organization transformation'. Human Relations, 42, 6, 463-85.

Schiffman, L. G. and Kanuk, L. L. (1991). Consumer Behavior. Englewood Cliffs, NJ: Prentice-Hall. 
Schultz, A. (1967). The Phenomenology of the Social World. Evaston: Northwestern University Press.

Sahwandt, T. A. (1997). Qualitative Inquiry. A Dictionary of Terms. Thousand Oaks: Sage.

Sheetz, S. D., Tegarden, D. P., Kozar, K. A. and Zigurs, I. (1994). 'A group support systems approach to cognitive mapping'. Journal of Management Information Systems, 11, 1, 31-57.

Sobol, M. G. and LeI, D. (1994). 'Environment, manufacturing technology and embedded knowledge'. International fournal of Human Factors in Manufacturing, 4, 2, 167-89.

Spender, J.-C. (1993). 'Competitive advantage from tacit knowledge? Unpacking the concept and its strategic implication'. Best Paper Proceedings, Annual Meeting of the Academy of Management, Atlanta, Georgia.

Spender, J.-C. (1994). 'Organizational knowledge, collective practice and Penrose rents'. International Business Review, 3-4, 1-5.

Spender, J.-C. (1996). 'Organizational knowledge, learning and memory: three concepts in search of a theory'. Journal of Organizational Change Management, 9, 1, 63-78.

Srivastava, S. and Barrett, F. J. (1988). 'The transforming nature of metaphors in group development: a study in group theory'. Human Relations, 41, 1, 31-64.

Sternberg, R. J. (1994). 'Tacit knowledge and job success'. In Anderson, N. and Herriot, P. (Eds), Assessment and Selection in Organizations: Methods and Practice for Recruitment and Appraisal. London: John Wiley, 27-39.

Thomas, W. I. and Thomas, D. S. (1928). The Child in America: Behavior, Problems and Progress. New York: Knopf.

Tsoukas, H. (1991). 'The missing link: a transformational view of metaphors in organizational science'. Academy of Management Review, 16, 3, 566-85.

WALSh, J. P. (1988). 'Selectivity and selective perception - an investigation of managers' belief structures and information processing'. Academy of Management Fournal, 31, 4, 873-93.

Weick, K. E. and Bougon, M. G. (1986). 'Organizations as cognitive maps'. In Sims, H. P. (Ed.), The Thinking Organization. San Francisco: Jossey-Bass, 1025-135.

Werner, O. and Schoepfle, G. M. (1987). Systematic Fieldwork, volume 1. Newbury Park: Sage.

Wernerfelt, B. (1984). 'A resource-based view of the firm'. Strategic Management Fournal, 5, 171-80.

Wilkins, A. L. and Thompson, M. P. (1991). 'On getting the story crooked and straight'. Journal of Organizational Change Management, 4, 3, 18-26.

Winter, S. G. (1987). 'Knowledge and competence as strategic assets'. In Teece, D. J. (Ed.), The Competitive Challenge. Cambridge, MA: Ballinger Publishing Company, 159-84.

Wright, R. W. (1994). 'The effects of tacitness and tangibility on the diffusion of knowledge-based resources'. Best Paper Proceedings, Annual Meeting of the Academy of Management, Dallas. 